\title{
Chronic Lymphocytic Leukemia Cells Lack the 185,000-Dalton Macromolecular Insoluble Cold Globulin Present on Normal B Lymphocytes
}

\author{
Mary A. Simmonds, Gloria Sobczak, and Stephen P. Hauptman, The Cardeza \\ Foundation for Hematologic Research, Department of Medicine, Thomas \\ Jefferson University, Philadelphia, Pennsylvania 19107
}

A B S TRACT We have recently characterized two lymphocyte-associated membrane proteins which have been termed 225,000-dalton and 185,000-dalton macromolecular insoluble cold globulin (225-MICG and 185MICG, respectively) to distinguish their major physicochemical properties. These proteins differ antigenically, structurally, and in their cellular distribution. $T$ cells can be distinguished by the synthesis and presence in the plasma membrane of 225-MICG, Null cells by the appearance of 185-MICG, and B cells by the appearance of both 225- and 185-MICG. The characterization of these two proteins in the monoclonal B lymphocytes of chronic lymphocytic leukemia forms the basis of this report.

Using immunofluorescent microscopy, we found only 225-MICG on the surface of chronic lymphocytic leukemia (CLL) cells in 15 patients, whereas control B cells from 20 individuals displayed both 225- and 185MICG. When MICG proteins were isolated and compared by sodium dodecyl sulfate-polyacrylamide gel electrophoresis, normal B cells showed two stained bands, corresponding to 225- and 185-MICG, whereas the CLL cells demonstrated only the 225-MICG band. Using labeled amino acid incorporation into cellular protein, normal B cells were shown to synthesize 225and 185-MICG, whereas CLL cells synthesized only 225-MICG, as determined by immune or cold precipitation of labeled cell lysates. When labeled secretions from B cells and CLL cells were analyzed by immune precipitation, 225- and 185-MICG were secreted by B cells, whereas neither protein was secreted by CLL cells. When normal B cells and CLL cells were mixed, incubated, and lysed together, both 225- and 185-

Address all correspondence to Dr. Stephen P. Hauptman, Cardeza Foundațion, Thomas Jefferson University, Philadelphia, Pa. 19107.

Received for publication 31 July 1980 and in revised form 3 November 1980.
MICG were present, thus excluding proteolysis as a cause of the absence of 185-MICG in CLL. The lack of 185-MICG in CLL distinguishes leukemic cells from normal B lymphocytes. Furthermore, the absence of this normal cell surface protein in these leukemic cells suggests a role for 185-MICG in the malignant transformation of lymphocytes.

\section{INTRODUCTION}

Monoclonal lymphocytes represent the product of a single clone of cells, in which the progeny demonstrate similar cell surface markers and functions to normal subpopulations (1-7). Chronic lymphocytic leukemia (CLL) ${ }^{1}$ has been shown to be a monoclonal malignant disorder with properties of normal B cells, i.e., the cells bear surface immunoglobin (SIg), usually IgM, IgD, or both, of a single light and heavy chain isotype (8-13). The monoclonal SIg on CLL cells has been shown to have antibody activity, supporting the concept that SIg on normal B cells is the receptor responsible for antigen recognition $(1,2)$. Cell surface marker characterization of various malignant clones has also suggested pathways along which normal lymphocyte differentiation could progress $(14,15)$. In this regard, certain patients with acute leukemia have been shown to have a pre-B cell type, containing cytoplasmic IgM, but not SIgM (16). An analogous situation has been demonstrated in the ontogeny of $B$ cells, in which

\footnotetext{
${ }^{1}$ Abbreviations used in this paper: CLL, chronic lymphocytic leukemia; FCS, fetal calf serum; FHC, Ficoll-Hypaque centrifugation; FITC, fluorescein isothiocyanate; GAHIgM, goat anti-human IgM; GARIgG, goat anti-rabbit IgG; 185- (or 225-) MICG, 185,000-dalton (or 225,000-dalton) macromolecular insoluble cold globulin; N cells, null cells; PAGE, polyacrylamide gel electrophoresis; $\mathrm{PBL}$, peripheral blood mononuclear cell; SIg, surface immunoglobulin; SRBC, sheep erythrocyte; TRITC, tetramethyl rhodamine isothiocyanate.
} 
a pre-B precedes development of the normal $\mathrm{B}$ cell (17). Although much useful information has been obtained by analysis of surface antigens on malignant lymphocytes, these studies have not revealed mechanisms by which clonal growth could be controlled.

We have recently demonstrated that human lymphocytes can be further delineated by the presence of two macromolecules, 225,000- and 185,000-dalton macromolecular insoluble cold globulin (225-MICG and 185MICG) (18-20). These proteins are antigenically distinct and can be used to distinguish lymphocyte classes. $T$ lymphocytes synthesize and have on their plasma membrane 225-MICG; null cells ( $\mathrm{N}$ cells), defined as non- $T$ and non-B lymphocytes, synthesize and insert into their plasma membrane 185-MICG; and B cells synthesize and have on their plasma membrane both 225- and 185-MICG.

The present study was undertaken to determine whether CLL B cells were phenotypically similar to normal $\mathrm{B}$ cells in regard to the MICG proteins. The results demonstrate that a major glycoprotein, 185-MICG, is absent from and not synthesized by CLL cells, and in addition, these lymphocytes do not secrete 225-MICG as do normal B cells.

\section{METHODS}

Isolation of human lymphocytes and subpopulations. Peripheral blood mononuclear cells (PBL) from patients and controls were separated from $30 \mathrm{ml}$ of heparinized whole blood or from by-products of plateletpheresis (kindly donated by the Thomas Jefferson University Hospital Donor Center and the Penn-Jersey Chapter of the American Red Cross, Philadelphia, Pa.) by Ficoll-Hypaque centrifugation (FHC) $(20-22)$. $T$ cells in these preparations were enumerated by rosette formation with neuraminidase-treated sheep erythrocytes (SRBC) and separated from PBL by rosette sedimentation on Ficoll-Hypaque in RPMI-1640, as previously described $(19,23,24)$. The $T$ lymphocytes contained $<1 \% \mathrm{SIg}^{+}$cells, and $97 \%$ of these cells formed rosettes with SRBC, and thus were $\mathrm{E}^{+}$. Unrosetted cells at the Ficollmedium interface are referred to as B lymphocytes and contained $93 \% \mathrm{SIg}^{+}$cells and $<1 \% \mathrm{E}^{+}$cells. To identify $\mathrm{SIg}^{+}(\mathrm{B})$ cells, fluorescent microscopy was performed using fluorescein isothiocyanate (FITC)-conjugated rabbit anti-human Fab (Behring Diagnostics, Sommerville, N. J.) (25). In the case of CLL cells, B cells were typed for IgM, IgD, IgG, $\kappa$, and $\lambda$ using rabbit anti-human immunoglobulin FITC-specific antiserum (Behring Diagnostics). B cells were also counted by rosetting with SRBC coated with IgM antibody and complement (26). Cell viability after separation was determined by exclusion of $0.05 \%$ ( $\mathrm{vol} / \mathrm{vol}$ ) trypan blue in phosphate-buffered saline, and was $>95 \%$. If cells were to be left overnight, they were routinely placed in $10 \%$ fetal calf serum (FCS) at $4^{\circ} \mathrm{C}$; otherwise, there was a considerable loss of 185 MICG. All experiments with CLL B cells were done after the PBL were depleted of T cells, and will hereafter be referred to simply as CLL cells.

The 15 patients with CLL all had leukocyte counts of 50,000/ $\mathrm{mm}^{3}$ or higher and $>90 \%$ lymphocytes. Furthermore, B cells were separated from T cells by FHC, and the B cells were subjected to immunofluorescence with FITC-conjugated rabbit anti-human $\kappa$ or $\lambda$ antiserum. Under these conditions the CLL B cells stain lightly compared with normal B cells and $98 \%$ of these cells were positive for either $\kappa$ or $\lambda$. The 15 cases reported were chosen this way for further study.

Cell culture conditions for protein synthesis and secretion. Single cell suspensions $\left(10-50 \times 10^{6}\right)$ were incubated in the absence of FCS in $3 \mathrm{ml}$ of Eagle's minimum essential medium lacking leucine or arginine (Gibco Laboratories, Grand Island Biological Co., Grand Island, N. Y.), with $10 \mu \mathrm{Ci}$ of $\left[{ }^{14} \mathrm{C}\right] \mathrm{leu}-$ cine (specific activity $335 \mathrm{mCi} / \mathrm{mmol}$ ), $50 \mu \mathrm{Ci}$ of $\left[{ }^{3} \mathrm{H}\right]$ leucine (specific activity $111.2 \mathrm{Ci} / \mathrm{mmol}$ ), $10 \mu \mathrm{Ci}$ of $\left[{ }^{14} \mathrm{C}\right]$ arginine (specific activity $336 \mathrm{mCi} / \mathrm{mmol}$ ), or $100 \mu \mathrm{Ci}$ of $\left[{ }^{3} \mathrm{H}\right]$ arginine (specific activity $21 \mathrm{Ci} / \mathrm{mmol}$ ), all from New England Nuclear, Boston, Mass., as described (19, 20, 27, 28). The cells were incubated for $4 \mathrm{~h}$ at $37^{\circ} \mathrm{C}$ in a mixture of $95 \%$ air- $5 \% \mathrm{CO}_{2}$ in a humidified atmosphere $(29,30)$. The radiolabeled cells were then immersed in ice water, made $0.06 \mathrm{M}$ in iodoacetamide, and centrifuged at $400 \mathrm{~g}$ for $10 \mathrm{~min}$. The supernates were collected and termed "secretions." The cells were washed extensively and resuspended in $1.5 \mathrm{ml}$ of isotonic buffer, pH 7.2 (29).

Detergent lysis of radiolabeled cells and immune precipitation of cell lysates and of secretion. Desoxycholate (Fischer Scientific Co., Fairlawn, N. J.) was added to the radiolabeled cell suspension to yield a final concentration of $0.5 \%$ ( $\mathrm{vol} / \mathrm{vol})$, and the mixture was made $0.12 \mathrm{M}$ with respect to iodoacetamide and $1,000 \mathrm{U} / \mathrm{ml}$ with respect to Trasylol (Calbiochem-Behring Corp., American Hoechst Corp., San Diego, Calif.) added (19). After incubation for $20 \mathrm{~min}$ at $4^{\circ} \mathrm{C}$, the resultant cell lysate was centrifuged at $105,000 \mathrm{~g}$ for $30 \mathrm{~min}$ at $4^{\circ} \mathrm{C}$; the pellet was discarded. Radiolabeled lysates and secretions in a volume of 1.6 or $3.0 \mathrm{ml}$, respectively, were immune precipitated by the direct technique using anti-225-MICG antiserum $(250 \mu \mathrm{l})$, anti-185-MICG $(250 \mu \mathrm{l})$, or antiserum with reactivity toward both 225 - and 185-MICG, i.e., anti-225 +185 -MICG antiserum $(250 \mu \mathrm{l})$, in antibody excess. Incubation of antiserum with cell lysates proceeded at $4^{\circ} \mathrm{C}$ for $16 \mathrm{~h}$. Under these conditions, MICG proteins remained soluble, enabling MICG to be immune-precipitated from whole cell lysates. The precipitates were washed and dissolved in sodium dodecyl sulfate-urea buffer (see below).

Isolation of MICG by cold precipitation. Isolated cells were lysed in isotonic buffer containing $0.5 \%$ Nonidet P-40 as previously described, with the exception that the iodoacetamide concentration was increased to $0.12 \mathrm{M}(19,20,27,28)$. The cell lysates were centrifuged at $105,000 \mathrm{~g}$ for $30 \mathrm{~min}$ at $4^{\circ} \mathrm{C}$, the pellet discarded, and the supernate incubated at $4^{\circ} \mathrm{C}$ for $24 \mathrm{~h}$. The cold precipitate was solubilized in $1 \%$ (wt/vol) sodium dodecyl sulfate (SDS)- $8 \mathrm{M}$ urea-0.06 M iodoacetamide-Trasylol (1,000 U/ml)-0.1 M Tris buffer, pH 9.2 (SDSurea buffer) $(19,20)$. Details of 225- and 185-MICG cold precipitation, preparation of anti-human MICG antisera, and SDS-polyacrylamide gel electrophoresis (SDS-PAGE) $(5 \%)$ have been previously reported $(18-20,27,28)$. Solubilized cold and immune precipitates were reduced with $0.5 \mathrm{M} \mathrm{2-}$ mercaptoethanol for $1 \mathrm{~h}$ at $37^{\circ} \mathrm{C}$, alkylated with $0.65 \mathrm{M}$ iodoacetamide, and then dialyzed (19). Protein determination was as previously described (3). Equal amounts of protein $(20-50 \mu \mathrm{g})$ were applied to gels that were to be directly compared.

Antiserum absorption. Heat-inactivated $\left(56^{\circ} \mathrm{C}\right)$ antiserum to human $225+185-\mathrm{MICG}$ was absorbed in $0.5 \mathrm{ml}$ aliquots with $700-750 \times 10^{6} \mathrm{~T}$ cells, normal B cells, or CLL cells for $3 \mathrm{~h}$ at $4^{\circ} \mathrm{C}$ with shaking. The mixtures were centrifuged at $1,000 \mathrm{~g}$ for $20 \mathrm{~min}$, and the supernate was collected. Antiserum absorbed in this fashion was stored at $-70^{\circ} \mathrm{C}$.

Immunofuorescence. Indirect immunofluorescence was performed on viable PBL and subpopulations as previously 
detailed $(19,25,31,32)$. Briefly, lymphocytes $\left(2 \times 10^{6}\right)$ were incubated for $1 \mathrm{~h}$ at $37^{\circ} \mathrm{C}$ in $3 \mathrm{ml}$ of minimum essential medium supplemented with $20 \%$ FCS and $0.2 \%$ sodium azide to remove cytophilic antibody. The cells were washed at $37^{\circ} \mathrm{C}$, resuspended in $0.1 \mathrm{ml}$ of medium without $\mathrm{FCS}$, and incubated at $4^{\circ} \mathrm{C}$ for $30 \mathrm{~min}$ with $0.1 \mathrm{ml}$ of anti-human 225-, anti-human 185-, or anti-human $225+185$-MICG antiserum (1:32). The antiserum employed was the IgG fraction (33). The cells were washed three times and resuspended in $0.1 \mathrm{ml}$ of medium, and $0.1 \mathrm{ml}$ of FITC-conjugated goat anti-rabbit IgG (GARIgG) (Behring Diagnostics) (1:32) was added. Incubation was continued for $30 \mathrm{~min}$ at $4^{\circ} \mathrm{C}$. The cells were washed three times and finally resuspended in $0.1 \mathrm{ml}$ of medium. A drop of the cell suspension was applied to a microscope slide with the bottom of a $12 \times 75$-mm test tube and fixed in ethanol (95\%), and a cover slip was applied in buffered glycerol (34).

Indirect immunofluorescence specificity controls consisted of normal rabbit IgG in place of rabbit anti-MICG and absorption experiments. Less than $1 \%$ of human PBL, T cells, $B$ cells, or CLL cells were immunofluorescent positive with normal rabbit IgG $(2 \mathrm{mg} / \mathrm{ml})$. Indirect immunofluorescence of all lymphocytes and subpopulations was completely blocked by absorption of anti-225 + 185-MICG antiserum with 750 $\times 10^{6} \mathrm{~B}$ lymphocytes or with isolated 225- and 185-MICG antigen $(50 \mu \mathrm{g})$. Rabbit anti-human MICG antisera and GARIgG antiserum were routinely absorbed with human immunoglobulin linked to Sepharose 4-B by the cyanogen bromide technique $(25,32)$. Immunoflourescence of all lymphocytes was blocked by prior absorption of FITC GARIgG with normal rabbit IgG linked to cyanogen bromide-activated Sepharose 4-B (35). Details of absorption have been previously described $(19,20)$.

Combined immunofluorescence. Direct immunofluorescence, using tetramethyl rhodamine isothiocyanate (TRITC)conjugated goat anti-human IgM (GAHIgM) antiserum (N. L. Cappel Laboratories, Inc., Cochranville, Pa.), was also performed on viable lymphocytes. PBL, T cells, or B cells $\left(2 \times 10^{6}\right)$ in $0.1 \mathrm{ml}$ of medium were incubated with $0.1 \mathrm{ml}$ of a $1: 16$ dilution of GAHIgM (TRITC) for $30 \mathrm{~min}$ at $4^{\circ} \mathrm{C}$ and further processed as in the indirect technique (see above) using various rabbit anti-MICG antisera and GARIgG (FITC) at $4^{\circ} \mathrm{C}$. In some experiments cells were stained for MICG first (indirect) and then stained for IgM (direct). Regardless of the sequence of reagents, the percentage and pattern of cells staining for either rhodamine or fluorescein were similar. Direct immunofluorescence was blocked by prior absorption of GAHIgM (TRITC) with human IgM linked to cyanogen bromide-activated Sepharose 4-B (35). There was no reaction of the CAHIgM with rabbit IgG or IgM as determined by immunoelectrophoresis.

The preparations were examined with a Zeiss IV FL-epifluorescent microscope equipped with an Osram $12 \mathrm{~V}, 100 \mathrm{~W}$ halogen lamp and an incident light fluorescence illuminator (Carl Zeiss, Inc., New York, N. Y.). The same field of cells was examined for fluorescein and rhodamine, and subjected to phase-contrast microscopy; 300 phase cells were counted as either FITC (green) or TRITC (red) $(19,20)$. The results were expressed as the percentage of FITC and/or TRITC positive cells per 100 phase-contrast cells. Photographs were recorded on Ektachrome ASA 400 film. In the Results section, quantitation of immunofluorescence on normal lymphocytes represents the mean of 35 controls studied with these antisera.

\section{RESULTS}

In previous studies we have shown that human $\mathrm{T}$ cells produce 225-MICG, whereas $\mathrm{N}$ cells synthesize an antigenically dissimilar protein, 185-MICG (18-20). However, we were unable to demonstrate the synthesis of either 225- or 185-MICG in B lymphocytes. Subsequent experiments have demonstrated the synthesis of both 225- and 185-MICG in B cells (Fig. 1). T cells were labeled with $\left[{ }^{3} \mathrm{H}\right]$ arginine and $\mathrm{B}$ cells with $\left[{ }^{14} \mathrm{C}\right]$ arginine, and the resultant cell lysates reacted with anti-225 $+185-$ MICG antiserum. This study demonstrated the synthesis of 225-MICG in T cells and B cells and the synthesis of 185-MICG in B cells alone.

Our inability previously to identify 225 - and 185MICG in B cells was due to the lability of these proteins in B cells. To isolate these proteins from normal B cells, the following conditions were found necessary. After isolation from PBL, B cells should be suspended in medium containing FCS, since in its absence most of the 225-MICG and all of the 185-MICG is lost during overnight storage at $4^{\circ} \mathrm{C}$. Furthermore, incubation of $\mathrm{B}$ cells at $37^{\circ} \mathrm{C}$ for $5-6 \mathrm{~h}$ causes the loss of $35 \%$ of the cold precipitable 185-MICG compared with control B cells processed immediately or kept for $5 \mathrm{~h}$ at $4^{\circ} \mathrm{C}$. Another important variable was the concentration of iodoacetamide during detergent lysis of $B$ cells. It was necessary to use a concentration of iodoacetamide of $0.1 \mathrm{M}$ or above to prevent loss of 185-MICG. Finally, when B cells were eluted from anti-Fab columns we consistently found that the SIg was capped, MICG was lost from the cell surface, and the capacity of the B cells

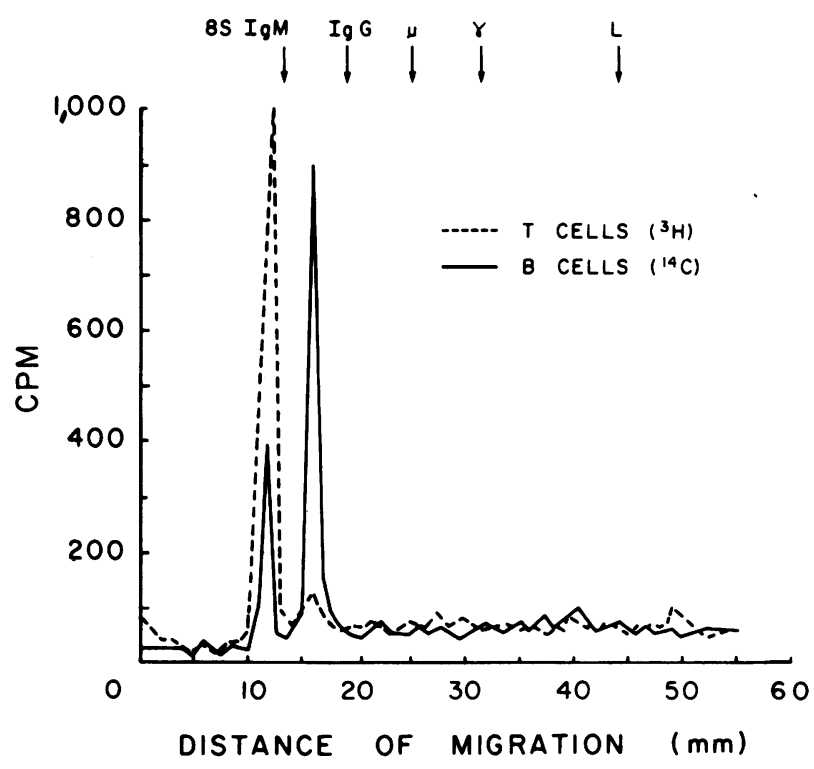

FIGURE 1 Synthesis of MICG in T and B cells. $50 \times 10^{6} \mathrm{~T}$ cells (----) were labeled with $\left[{ }^{3} \mathrm{H}\right]$ arginine, and $50 \times 10^{6} \mathrm{~B}$ cells (-), with $\left[{ }^{14} \mathrm{C}\right]$ arginine. The washed, labeled cells were lysed together and reacted with anti-225 + 185-MICG antibody. The precipitates were reduced and subjected to 5\% SDS-PAGE. Arrows indicate the position of labeled markers. Top of the gel is on the left-hand side of figure. $\mu$, IgM heavy chains; $\gamma$, IgG heavy chains; L, light chains. 

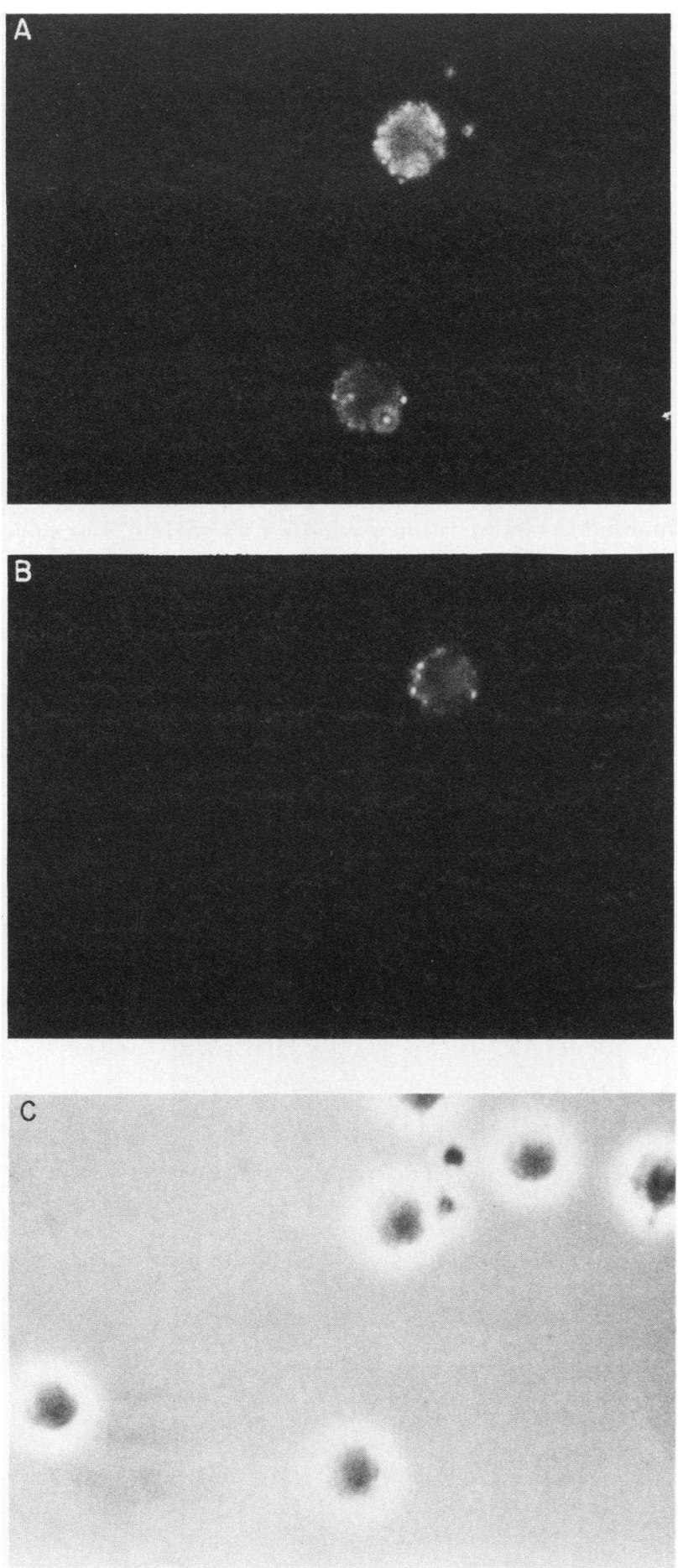

Figure 2 Combined immunofluorescence to show simultaneously the cell surface distribution of MICG and immunoglobulin. PBL were reacted with GAHIgM (TRITC) and the sensitized cells then treated with rabbit anti-human 185-MICG antibody followed by GARIgG (FITC). All incubations were for $30 \mathrm{~min}$ at $4^{\circ} \mathrm{C}$ in the presence of $0.2 \%$ sodium azide. The cells were washed and applied to slides in buffered glycerol and individual fields examined by immunofluorescent microscopy with selective filters for FITC (A), TRITC (B), or phase-contrast microscopy (C). to synthesize immunoglobulin as well as MICG was markedly impaired. In the following experiments, therefore, B cells were isolated by FHC, and no attempt was made to remove the $\mathrm{N}$ cells $\left(\mathrm{SIg}^{-}, \mathrm{E}^{-}\right)$from the $\mathrm{B}$ cell fractions.

With these conditions to preserve lymphocytes, the following results were obtained using combined IF. PBL were first reacted with GAHIgM (TRITC) to label SIg on B cells, washed, and then treated with rabbit anti185-MICG followed by GARIgG (FITC). All reactions were carried out at $4^{\circ} \mathrm{C}$. SIg (TRITC) was found on $12 \%$ of the PBL, whereas 185-MICG (FITC) was seen on $20 \%$ of the PBL (Fig. 2). All cells that were $\mathrm{SIg}^{+}$were $185-\mathrm{MICG}^{+}$, and in addition, $10 \%$ of the cells were 185 $\mathrm{MICG}^{+}$and $\mathrm{SIg}^{-}$. The results in Fig. 2A show that 185MICG is found on the cell surface of two of the PBL, only one of which is also $\mathrm{SIg}^{+}$(Fig. 2B). Using isolated T cells and combined immunofluorescence, $\mathrm{T}$ cells were found to be $98 \% 225-\mathrm{MICG}^{+},<1 \% 185-\mathrm{MICG}^{+}$, and $<1 \% \mathrm{SIg}^{+}$. In contrast, isolated B cells are $100 \% 185-$ $\mathrm{MICG}^{+}, 90 \%$ 225-MICG ${ }^{+}$, and $90 \% \mathrm{SIg}^{+}$. When the $225-$ MICG in B cells is detected as FITC and SIg as TRITC in combined immunofluorescence, there is complete overlap; all the B cells are positive for both 225-MICG and SIg. The following pattern has emerged: $T$ cells have only 225-MICG, N cells have only 185-MICG, and B cells have both 225- and 185-MICG.

To delineate these proteins in CLL cells, we isolated MICG from the B cell lysate of seven patients. The cold precipitates were analyzed on SDS-PAGE and compared with normal $T$ and $B$ cells (Fig. 3 ). T cells demonstrated a 225,000 dalton protein and normal B cells both a 225,000- and a 185,000-dalton protein (Fig. 3, left and middle). However, in CLL cells from all patients, only the 225,000-dalton protein was detected (Fig. 3, right).

Further evidence for the absence of 185-MICG in CLL cells was sought using immunofluorescence. Lymphocyte subpopulations were isolated and reacted with either anti-225 + 185-MICG or anti-185-MICG

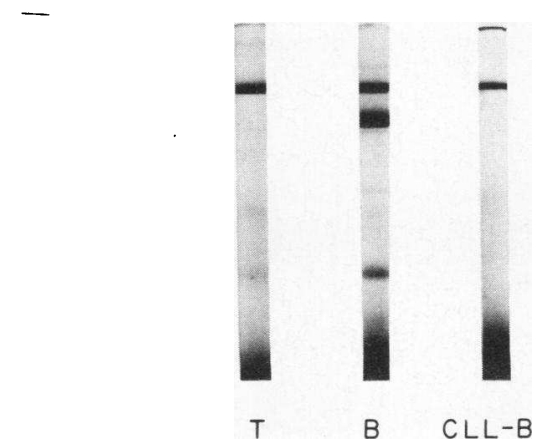

FIGURE 3 Isolation of 225- and 185-MICG from lymphocyte lysates derived from T cells $\left(50 \times 10^{6}\right)$, B cells $\left(50 \times 10^{6}\right)$, and CLL B cells $\left(50 \times 10^{6}\right)$. The lysates were cold precipitated and the isolated protein (25) $\mu \mathrm{g}$ ) reduced and subjected to $5 \%$ SDS-PAGE; the gels were stained with $0.5 \%$ coomassie blue. 
antiserum. The latter antiserum, made from the former antiserum by absorbing with $\mathrm{T}$ cells, reacted with labeled 185,000-dalton MICG and not with 225,000dalton MICG. Anti-225 + 185-MICG antiserum stained the cell surface of normal T, B, and CLL cells in a ringed pattern (Fig. 4A-C), whereas anti-185-MICG antiserum did not stain $\mathrm{T}$ cells (Fig. 4D), although it reacted with normal $\mathrm{B}$ cells (Fig. $4 \mathrm{E}$ ). In contradistinction, anti-185-MICG antiserum did not stain CLL cells (Fig. 4F). Identical results were obtained in fifteen other CLL patients. When normal B cells were used to absorb the anti-225 + 185-MICG antiserum, immunofluorescent staining disappeared for normal $\mathrm{T}$ and $\mathrm{B}$ cells, as well as for CLL cells. Finally, CLL cells were used to absorb the anti-225 + 185-MICG antiserum, and reactivity was retained for $B$ cells and lost for $T$ cells and CLL cells. Similarly, when PBL were stained with this antiserum and anti-IgM (TRITC) in combined immunofluorescence, a pattern similar to that of Fig. 2 was obtained, i.e., $\mathrm{SIg}^{+}$cells (B cells) were also stained with this absorbed antiserum.

To determine if CLL cells produce a protease that might cleave 185-MICG, equal numbers of normal and CLL B cells were mixed and incubated for $1 \mathrm{~h}$ at $37^{\circ} \mathrm{C}$ before detergent lysis. After cold precipitation of the mixed cell lysates, SDS-PAGE demonstrated both 225- and 185-MICG (Fig. 5). When equal amounts of protein from normal B cells, CLL cells, and mixed cells were compared by SDS-PAGE and densitometry tracing, there was no evidence of any loss of 185-MICG.

Although we were unable to demonstrate the presence of 185-MICG on the surface of CLL cells, it remained to be determined whether 185-MICG was synthesized in these cells and then secreted. Radiolabeled
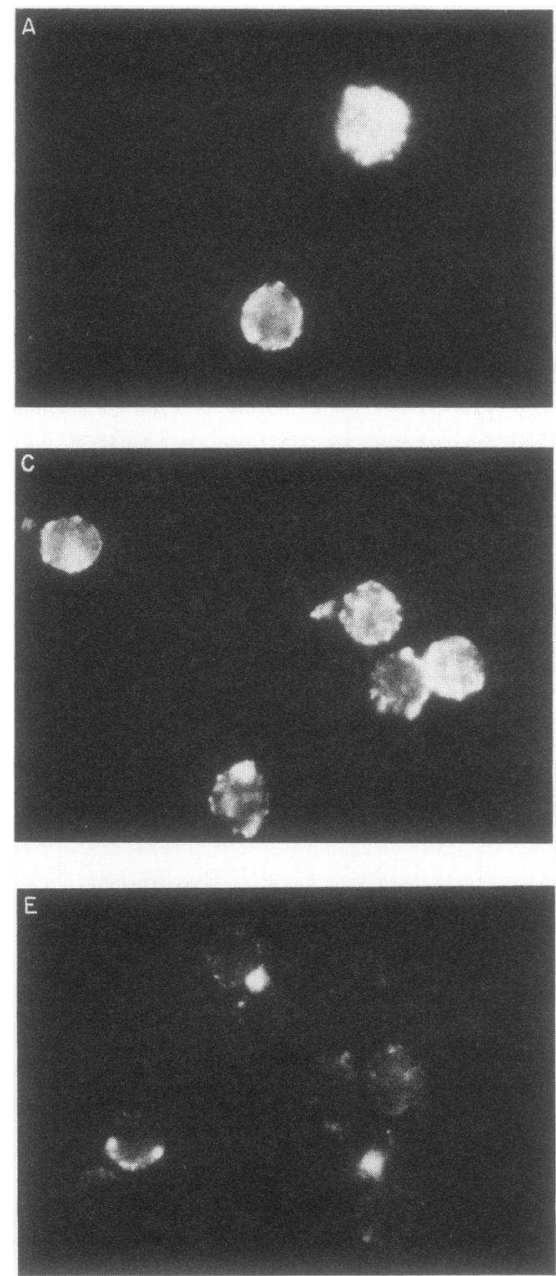
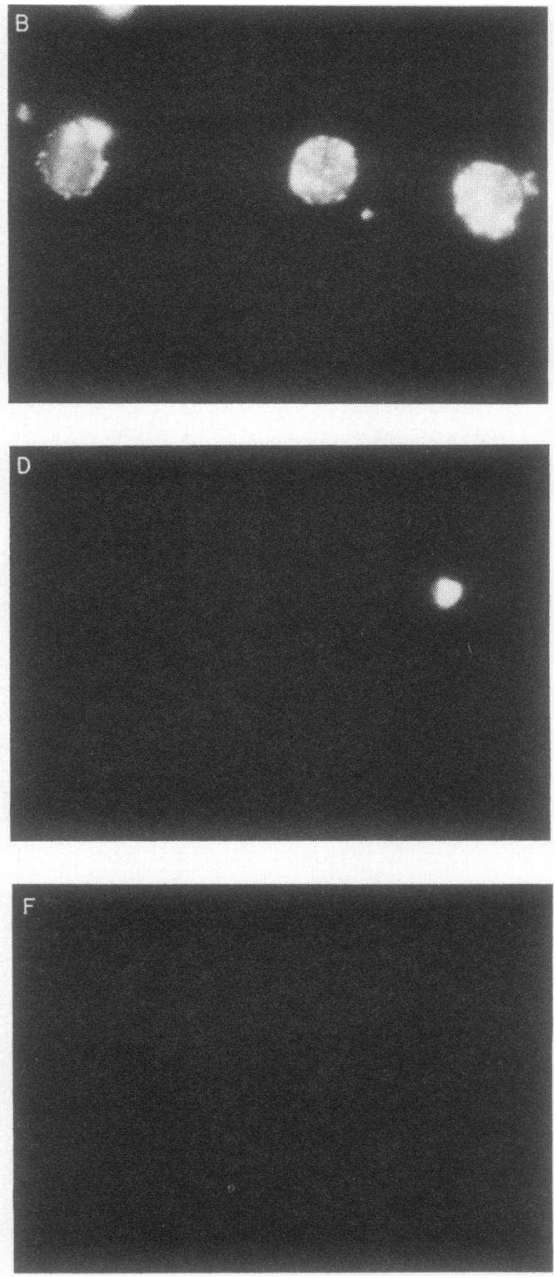

FIGURE 4 Cell surface distribution of MICG in isolated lymphocytes. T cells, B cells, or CLL cells were incubated with either anti-225 + 185-MICG antibody or anti-185-MICG antibody followed by GARIgG (FITC) for $30 \mathrm{~min}$ at $4^{\circ} \mathrm{C}$. After washing, a drop of the cell suspension was fixed on slides and examined with an epifluorescent microscope with selective filters for FITC and phase microscopy. A-C, cells incubated with anti-225 + 185-MICG antibody; D-F, cells incubated with anti-185-MICG antibody. A and D, T cells; B and E, B cells; C and F, CLL cells. 


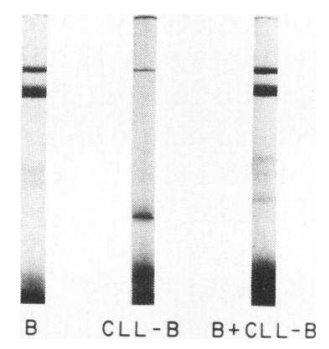

Figure 5 Simultaneous lysis of normal B cells and CLL cells. B cells $\left(50 \times 10^{6}\right)$ and CLL cells $\left(50 \times 10^{6}\right)$, either alone or mixed, were incubated for $1 \mathrm{~h}$ at $37^{\circ} \mathrm{C}$. The cells and mixtures were lysed in detergent and cold precipitated. The precipitates were reduced and electrophoresed on 5\% SDS gels and then stained with coomassie blue.

lysates and secretions from B cells and CLL cells were precipitated with anti-225 + 185-MICG antiserum and subjected to SDS-PAGE. Normal B cell lysates contained radiolabeled 225-MICG and 185-MICG (Fig. $6 a)$. When CLL cell lysates were immune precipitated, only 225-MICG was shown to be synthesized (Fig. 6c). Surprisingly, neither 225- nor 185-MICG was detected in the secretion from CLL cells (Fig. 6d), whereas normal $B$ cell secretions demonstrated the presence of both 225- and 185-MICG (Fig. 6b). Similar results were obtained when MICG was isolated from radiolabeled cell lysates by cold precipitation.

\section{DISCUSSION}

A considerable number of lymphoproliferative diseases have been recognized as monoclonal $B$ cell disorders. Chronic lymphocytic leukemia and the majority of lymphomas in adults are B cell malignancies $(11,12,36)$. In a given patient with CLL, all the leukemic cells will have either kappa or lambda-type immunoglobin on their cell surface, whereas normal B lymphocytes consist of a mosaic of kappa- and lambdacontaining cells in a ratio of $\sim 2: 1$ (10). The same CLL cell may have SIgM and SIgD, but both immunoglobulins then share a common idiotype, indicating that a single heavy chain variable region can be joined to different constant regions (37). These studies have helped to establish the concept that certain lymphoid malignancies might represent an aberrant expansion of a single transformed cell.

We have previously shown that $\mathrm{T}$ cells produce 225 MICG, and N cells produce 185-MICG $(19,20)$. Although both of these proteins were shown to be synthesized by and present on the cell surface of normal B cells, only 225-MICG was present in CLL B cells. The

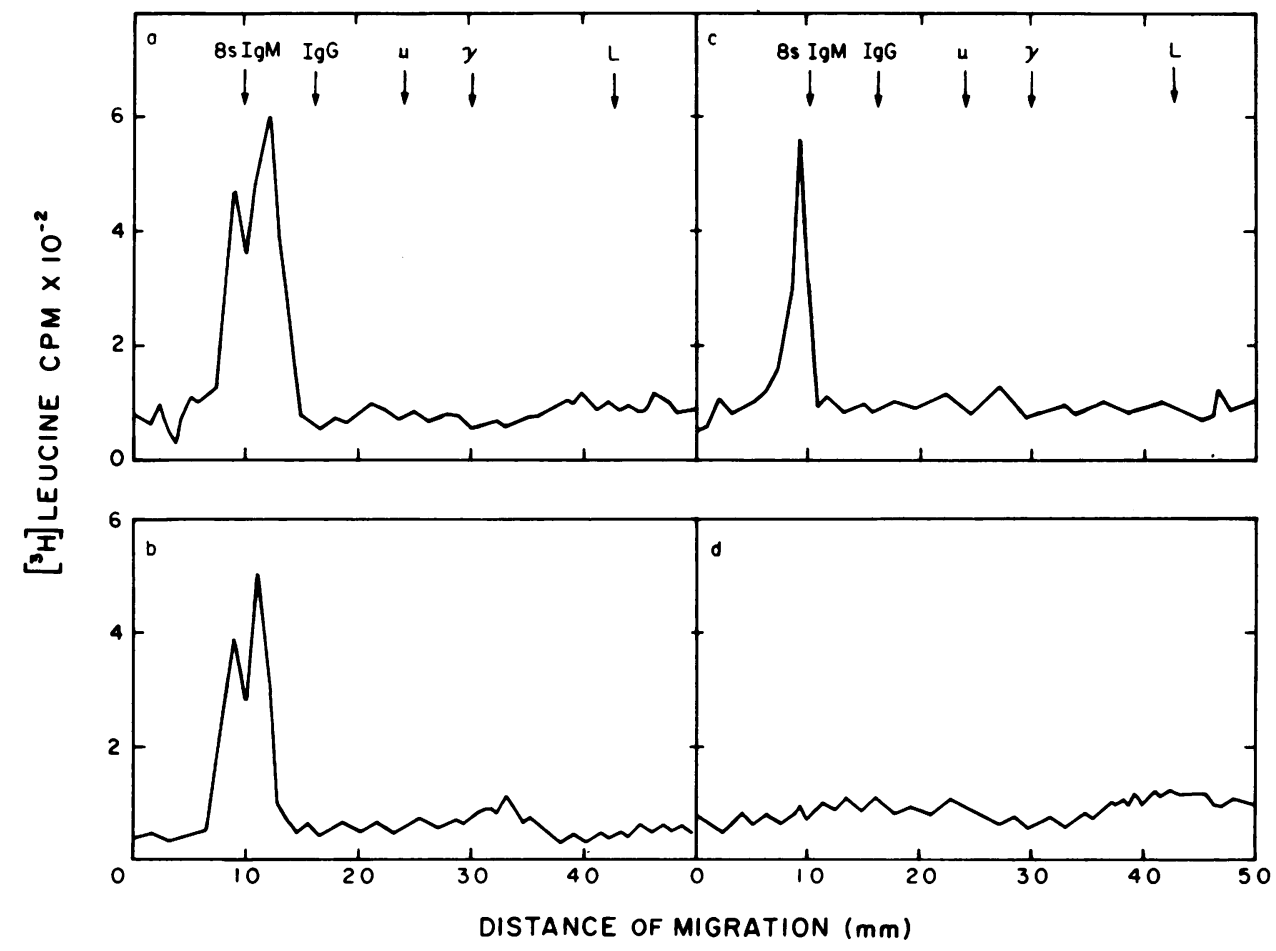

FIGURE 6 Immune precipitation of labeled lysates and secretions. B cells $\left(50 \times 10^{6}\right)$ and CLL cells $\left(50 \times 10^{6}\right)$ were labeled with $\left[{ }^{3} \mathrm{H}\right]$ leucine for $3 \mathrm{~h}$ at $37^{\circ} \mathrm{C}$. The secretions and cell lysates were reacted with anti-225 + 185-MICG antiserum and the precipitates reduced and electrophoresed on 5\% SDS-PAGE. (a) B cell lysates treated with antiserum. (b) B cell secretions treated with antiserum. (c) CLL cell lysates reacted with antiserum. (d) CLL cell secretions reacted with antiserum. 
various techniques utilized confirmed the absence of 185-MICG in CLL cells. Two possibilities were considered to explain the absence of 185-MICG from CLL cells. First, the leukemic cells could produce an enzyme that selectively cleaves 185 -MICG. This possibility was excluded by mixing normal B and CLL cells. No evidence of a protease cleaving 185-MICG was found in CLL cells. Second, it was possible that 185-MICG was not synthesized and/or was not cold precipitable in CLL cells. It was shown that CLL cells do not synthesize 185-MICG, although they do synthesize 225-MICG, as do normal $\mathrm{B}$ and $\mathrm{T}$ cells.

Since normal B cells secrete 225- and 185-MICG into the medium, we determined the capacity of CLL lymphocytes to secrete 225-MICG. The studies showed that leukemic B cells did not secrete 225-MICG into the medium. In previous reports it has been demonstrated that there is a lack of immunoglobulin secretion from CLL lymphocytes $(38,39)$. In contrast to our secretory study, which was accomplished in $4 \mathrm{~h}$ without FCS and mitogen, these studies cultured CLL cells for $6 \mathrm{~d}$ and used FCS and mitogen. Under the latter conditions it is thought that lymphocytes differentiate into plasma cells (40-42). Furthermore, secretion of immunoglobulin from normal lymphocytes is only a fraction of that from plasma cells (43-45). Since CLL lymphocytes are unable to differentiate further from a lymphocyte to a plasma cell after induction by antigen or mitogen, it is difficult to determine whether there is really a lack of immunoglobulin secretion or whether in fact there is simply not further differentiation to the secretory plasma cell stage. Our studies indicate that CLL cells display a secretory defect of 225-MICG, a protein normally synthesized in these cells.

The mechanism of cell proliferation in CLL remains obscure. It has been proposed that malignant cells might lose an essential cell surface protein that is responsible for promoting contact inhibition of cell growth $(46,47)$. In the absence of this protein, clonal expansion would go unchecked, and malignant proliferation could result. In this respect, CLL cells are known to be of monoclonal origin, and in addition display some unusual characteristics. In contrast to normal B lymphocytes, CLL cells smudge when smeared on a slide, lack the ability to form caps, and as we have shown, lack the ability to synthesize 185-MICG and to secrete 225-MICG $(48,49)$. The biological significance of the absence of 185-MICG in CLL might be related to these abnormal properties. In studies to be separately reported, we have shown that normal B cells, depleted of 185-MICG, display properties similar to leukemic lymphocytes.

Finally, it is possible that the absence of 185-MICG is a better indicator of a leukemic B cell than is the monoclonal immunoglobulin on its surface. If there is a large population of leukemic cells, it is rather simple to determine the monoclonal immunoglobulin nature of the disorder, but if the leukemic cell population is small, and accompanied by a normal number of $\kappa$ - and $\lambda$-containing cells, then it is difficult, if not impossible, to establish the monoclonal nature of the small population. The absence of 185-MICG would positively identify the $\mathrm{SIg}^{+}$leukemic cell.

\section{ACKNOWLEDGMENTS}

We wish to thank Maryann Serno and Jill Beal for their expert technical assistance.

This work was supported by National Institutes of Health grants CA 26369-01 and AM 07084.

\section{REFERENCES}

1. Preud'Homme, J. L., and M. Seligmann. 1972. Surface bound immunoglobulins as a cell marker in human lymphoproliferative diseases. Blood. 40: 777-794.

2. Preud'Homme, J. L., J. C. Brouet, J. P. Clauvel, and M. Seligmann. 1974. Surface IgD in immunoproliferative disorders. Scand. J. Immunol. 3: 853-858.

3. Hauptman, S. P., and T. B. Tomasi. 1974. Antibodies to human albumin in cirrhotic sera. J. Clin. Invest. 54: $122-127$.

4. Rosen, P. J., D. I. Feinstein, P. K. Pattengale, B. H. Tindle, A. H. Williams, M. J. Cain, J. B. Bonorris, J. W. Parker, and R. J. Lukes. 1978. Convoluted lymphocytic lymphoma in adults. A clinicopathologic entity. Ann. Int. Med. 89: 319-324.

5. Broder, S., R. L. Edelson, M. A. Lutzner, D. L. Nelson, R. P. MacDermott, M. E. Durm, C. K. Goldman, B. D. Meade, and T. A. Waldmann. 1976. The Sézary syndrome. A malignant proliferation of helper T cells.J. Clin. Invest. 58: 1297-1306.

6. Kansu, E., and S. P. Hauptman. 1979. Suppressor cell population in Sézary syndrome. Clin. Immunol. Immunopathol. 12: 341-350.

7. Zucker-Franklin, D., J. W. Melton, and F. Quagliata. 1974. Ultrastructural, immunologic, and functional studies on Sézary cells: a neoplastic variant of thymus-derived (T) lymphocytes. Proc. Natl. Acad. Sci. U. S. A. 71: $1877-1881$.

8. Aisenberg, A. C., and K. C. Block. 1972. Immunoglobulins and the surface of neoplastic lymphocytes. N. Engl. J. Med. 287: 272-276.

9. Seligmann, M., J. L. Preud'Homme, and J. C. Brouet. 1973. T and B lymphocytes in humans. Transplant. Rev. 16: $1-217$.

10. Ross, G. D., E. M. Rabellino, M. J. Polley, and H. M. Grey. 1973. Combined studies of complement receptor and surface immunoglobulin-bearing cells and sheep erythrocyte rosette-forming cells in normal and leukemic human lymphocytes. J. Clin. Invest. 52: 377-385.

11. Fialkow, P. J., A. L. Reddy, V. Najfeld, J. Singer, and L. Steinman. 1978. Chronic lymphocytic leukemia. Clonal origin in a committed B-lymphocyte progenitor. Lancet. II: $444-446$.

12. Fu, S. M., R. J. Winchester, and H. G. Kunkel. 1974. Occurrence of surface IgM, IgD and free light chains on human lymphocytes. J. Exp. Med. 139: 451-456.

13. Rowe, D. S., K. Hug, L. Forni, and B. Pernis. 1973. Immunoglobulin D as a lymphocyte receptor. J. Exp. Med. 138: 965-972.

14. Touraine, J. L., J. W. Hadden, and R. A. Good. 1977. Sequential stages of human $\mathrm{T}$ lymphocyte differentiation. Proc. Natl. Acad. Sci. U. S. A. 74: 3414-3418.

15. Boumsell, L., A. Bernard, H. Coppin, Y. Richard, C. Penit, 
P. Rouget, J. Lemerle, and J. Dausset. 1979. Human T cell differentiation antigens and correlation of their expression with various markers of $\mathrm{T}$ cell maturation. J. Immunol. 123: 2063-2067.

16. Vogler, L. B., W. M. Crist, D. E. Bockman, E. R. Pearl, A. R. Lawton, and M. D. Cooper. 1978. Pre-B-cell leukemia. A new phenotype of childhood lymphoblastic leukemia. N. Engl. J. Med. 298: 872-878.

17. Lay, C. Y., F. Melchers, R. G. Miller, and R. A. Phillips. 1979. In vitro generation of B lymphocytes from pre-Bcells. J. Immunol. 122: 1273-1277.

18. Hauptman, S. P., and E. Kansu. 1978. T cell origin of human macromolecular insoluble cold globulin. Nature (Lond.). 276: 393-394.

19. Hauptman, S. P., E. Kansu, M. Serno, and S. Godfrey. 1979. Human macromolecular insoluble cold globulin (MICG). I. T-cell origin of T-MICG and Null cell origin of N-MICG. J. Exp. Med. 149: 158-171.

20. Hauptman, S. P., E. Kansu, G. Sobczak, and M. Serno. 1979. Human macromolecular insolubale cold globulin (MICG). II. Immunologic definition of $\mathrm{T}$ cell and Null cell MICG and the biological effect of antiserum to MICG. J. Immunol. 122: 1035-1040.

21. Boyum, A. 1978. Isolation of mononuclear cells and granulocytes from human blood.J. Clin. Lab. Invest. 21(Suppl. 97): 77-89.

22. Alderson, E., J. P. Birchall, and J. J. T. Owen. 1976. A simple method of lymphocyte purification from human peripheral blood. J. Immunol. Methods. 11: 297-301.

23. Greaves, M. F., and G. Brown. 1974. Purification of human $\mathrm{T}$ and B lymphocytes. J. Immunol. 112: 420-423.

24. Aiuti, F., J. C. Cerottini, R. A. Coombs, M. Cooper, H. B. Dickler, S. Froland, H. H. Fudenberg, M. F. Greaves, H. M. Grey, H. G. Kunkel, J. Natvig, J. L. Preud'Homme, E. Rabellino, R. E. Ritts, D. S. Rowe, M. Seligmann, F. P. Siegal, J. Stjernsward, W. D. Terry, and J. Wybran. 1975. Identification, enumeration and isolation of $B$ and $T$ lymphocytes from human peripheral blood. Clin. Immunol. Immunopathol. 3: 584-597.

25. Higmans, W. H., H. R. E. Schuit, and F. Klein. 1969. An immunofluorescence procedure for the detection of intracellular immunoglobulins. Clin. Exp. Immunol. 4: 457-472.

26. Bianco, C., R. Patrick, and V. Nussenzweig. 1970. A population of lymphocytes bearing a membrane receptor for antigen-antibody-complement complexes. J. Exp. Med. 132: 702-729.

27. Hauptman, S. P. 1978. Macromolecular insoluble cold globulin (MICG): a novel protein from mouse lymphocytes. I. Isolation and characterization. Immunochemistry. 15: 415-422.

28. Hauptman, S. P., G. Sobczak, and I. A. Gutterman. 1978. Macromolecular insoluble cold globulin. (MICG): a novel protein from mouse lymphocytes. II. T-cell origin of MICG and response to mitogens. Immunochemistry. 15: 423-428.

29. Laskov, R., and M. D. Scharff. 1970. Synthesis, assembly and secretion of gamma globulin by mouse myeloma cells. I. Adaptation of the Merwin plasma cell tumor11 to culture, cloning and characterization of gamma globulin subunits. J. Exp. Med. 131: 515-541.

30. Laskov, R., R. Lanzerotti, and M. D. Scharff. 1971. Synthesis, assembly and secretion of gamma globulin by mouse myeloma cells. II. Assembly of $\operatorname{IgG}_{2 b}$ immunoglobulin by MPC II tumor and culture cells. J. Mol. Biol. 56: 327-339.

31. Pernis, B., L. Forni, and L. Amante. 1970. Immunoglobulin spots on the surface of rabbit lymphocytes. J. Exp. Med. 132: 1001-1018.
32. Hauptman, S. P., E. Kansu, and S. Godfrey. 1979. Macromolecular insoluble cold globulin (MICG): a novel protein from mouse lymphocytes. IV. Evidence for the plasma membrane distribution of MICG.J. Immunol. 123: 1007-1013.

33. Stanworth, D. R. 1960. A rapid method of preparing pure serum gamma globulin. Nature. (Lond.). 188: 156-157.

34. Preud'Homme, J. L., and M. Seligmann. 1972. Antihuman immunoglobulin $G$ activity of membranebound monoclonal immunoglobulin $\mathbf{M}$ in lymphoproliferative disorder. Proc. Natl. Acad. Sci. U. S. A. 69: 2132-2135.

35. Hauptman, S. P., and T. B. Tomasi, Jr. 1974. A monoclonal IgM protein with antibody-like activity for human albumin. J. Clin. Invest. 53: 932-940.

36. Aisenberg, A. C., K. J. Block, and J. C. Long. 1973. Cell-surface immunoglobulins in chronic lymphocytic leukemia and allied disorders. Am. J. Med. 55: 184-191.

37. Fu, S. M., R. J. Winchester, and H. J. Kunkel. 1975. Similar idiotype specificity for the membrane IgD and IgM of human B lymphocytes. J. Immunol. 114: 250-254.

38. Maino, V. C., J. T. Kurnick, R. T. Kubo, and H. M. Grey. 1977. Mitogen activation of human chronic lymphatic leukemia cells. I. Synthesis and secretion of immunoglobulin. J. Immunol. 118: 742-748.

39. Chen, Y., and P. Heller. 1978. Lymphocyte surface immunoglobulin density and immunoglobulin secretion in vitro in chronic lymphocytic leukemia (CLL). Blood. 52: 601-608.

40. Janossy, G., M. Shohat, M. F. Greaves, and R. R. Dourmashkin. 1973. Lymphocyte activation. IV. An ultrastructural pattern of the response of mouse $\mathrm{T}$ and $\mathrm{B}$ cells to mitogenic stimulation in vitro. Immunology. 24: 211-227.

41. Parkhouse, R. M. E., G. Janossy, and M. F. Greaves. 1972. Selective stimulation of IgM synthesis in mouse B lymphocytes by pokeweed mitogen. Nature New Biology. 235: 21-23.

42. Anderson, J., and F. Melchers. 1973. Induction of immunoglobulin $\mathrm{M}$ synthesis and secretion in bone-marrowderived lymphocytes by locally concentrated concanavalin A.Proc. Natl. Acad. Sci. U. S. A. 70: 416-420.

43. Vitetta, E. S., and J. W. Uhr. Cell surface immunoglobulin. 1974. IX. A new method for the study of synthesis, intracellular transport and exteriorization in murine splenocytes. J. Exp. Med. 139: 1599-1620.

44. George, E. R., and H. J. Cohen. 1979. Kinetics of immunoglobulin synthesis and secretion by resting and pokeweed mitogen-transformed human lymphocytes. Clin. Immunol. Immunopathol. 12: 94-104.

45. Janossy, G., E. G. DeLa Concha, A. Luquetti, M. J. Snajdr, M. J. Waxdal, and T. A. E. Platts-Mills. 1977. T-cell regulation of immunoglobulin synthesis and proliferation in pokeweed ( $\mathrm{Pa}-1)$-stimulated human lymphocyte cultures. Scand. J. Immunol. 6: 109-123.

46. Zetter, B. R., G. R. Martin, C. R. Birdwell, and D. Gospodarowicz. 1978. Role of the high-molecular-weight glycoprotein in cellular morphology, adhesion and differentiation. Ann. N. Y. Acad. Sci. 312: 299-316.

47. Chen, L. B., P. H. Gallimore, and J. K. McDougall, 1976. Correlation between tumor induction and large external transformation sensitive protein on the cell surface. Proc. Natl. Acad. Sci. U. S. A. 73: 3570-3574.

48. Rundles, R. W. 1972. Chronic lymphocytic leukemia. In Hematology. W. J. Williams, E. Beutler, A. J. Erslev, and R. W. Rundles, editors. McGraw-Hill Book Company, Inc., New York. 880-891.

49. Cohen, H. J. 1975. Human lymphocyte surface immunoglobulin capping. J. Clin. Invest. 55: 84-93. 